\title{
The nutritive value of forage sorghum genotypes developed for the dry tropical highlands of Kenya as feed source for ruminants
}

\author{
J.O. Ouda ${ }^{1,4 \#}$, G.K. Njehia ${ }^{1}$, A.R. Moss ${ }^{2}$, H.M. Omed ${ }^{3}$ and I.V. Nsahlai ${ }^{4}$ \\ ${ }^{1}$ KARI Beef Research Centre, P.O. Box 14912, Nakuru, Kenya \\ ${ }^{2}$ Nutritional Sciences Research Unit, School of Agriculture, Policy and Development, University of Reading, \\ RG6 6AR, UK \\ ${ }^{3}$ School of Agricultural \& Forest Sciences, University of Wales, Bangor, Gwynedd, LL57 2UD, UK \\ ${ }^{4}$ University of KwaZulu-Natal, Pietermaritzburg, Private bag X01, Scottsville, Pietermaritzburg 3209, South Africa
}

\begin{abstract}
In vitro studies were conducted on five sorghum genotypes developed for the dry tropical highland climate of Kenya and which can be fed to ruminants fresh or as silage. The five sorghum genotypes consisted of two normal white mid-rib (WMR) genotypes, coded E1291 and E65181, and three brown-midrib (BMR) genotypes, coded Lan-5, Lan-6 and Lan-12. Whole mature plants (herbage plus grain) and silage made from E1291 were used in the study. An in vitro manual gas production technique was used to compare the nutritive characteristics of these genotypes for ruminants. These sorghums differed significantly in true organic matter degraded (OMDeg), which ranged from 520 to $678 \mathrm{~g} / \mathrm{kg}$ after $24 \mathrm{~h}$ incubation and 706 to 805 $\mathrm{g} / \mathrm{kg}$ after $72 \mathrm{~h}$ incubation. All the BMR sorghums had a higher degradability than the WMR genotype, E6518, and the silage, with Lan-5 having the highest degradability. Methane produced per g OMDeg ranged from 40.6 to $46.4 \mathrm{~mL} / \mathrm{g}$ after $24 \mathrm{~h}$ incubation and from 53.1 to $62.6 \mathrm{~mL} / \mathrm{g}$ after $72 \mathrm{~h}$ incubation. It was similar for all genotypes after $24 \mathrm{~h}$ incubation but Lan-12 had the highest methane production after $72 \mathrm{~h}$ incubation. After $24 \mathrm{~h}$ and $72 \mathrm{~h}$ incubation all the genotypes produced a similar total amount of gas per OMDeg (293 to 309 and 357 to $385 \mathrm{~mL} / \mathrm{g}$, respectively) with similar total short chain fatty acid concentrations in the liquid digesta (7.8 to 10.4 and 9.5 to $10.3 \mathrm{mmol}$, respectively) and acetate to propionate ratios of 2.16 to 2.49 and 2.35 to 2.87 , respectively. The sorghums showed great potential as ruminant feed sources in the region.
\end{abstract}

Keywords: Sorghums, nutritive characteristics, in vitro gas production

\# Corresponding author. E-mail: jackouda@hotmail.com

\section{Introduction}

Sorghum (Sorghum bicolor (L.) Moench) is the third most prevalent grain produced in the world (McCollough et al., 1972) and the second most important cereal after maize under smallholder production in Kenya. Similar to maize, sorghum can be used as a dual-purpose crop but is often discounted by cattle feeders because of variable grain quality and poorer feed conversion efficiency (McCollough et al., 1972). However, the potential of sorghum for improvement of dryland livestock production has been recognised in many parts of the world. Meeske et al. (1993), for example, observed that sorghum is becoming a more important fodder crop in the dry tropical and sub-tropical regions owing to its high yields and drought resistance potential, and could replace maize. This could be important in a situation such as in Kenya where human resettlement is rapidly expanding into marginal areas frequented with crop failures (Anindo \& Topps, 1993).

The role of ruminants as primary converters of plant cell-wall material to animal products is dependent on the ruminal degradability of the consumed forages. A limiting factor to the degradability is the presence of lignin in the plant cell wall. Therefore, efforts to reduce lignin in ruminant forage diets would improve productivity. Gourley et al. (1997) observed that plants with the natural genetically controlled brown-midrib (BMR) trait produced less lignin than normal plants, making their fibres easily digestible by ruminants. Pedersen (1996) observed that BMR sorghum mutants have an increased digestibility due to a low lignin concentration. Similarly, Gourley et al. (1997) showed that germ plasm sources of BMR sorghum and Sudan grass (Sorghum sudanance (Piper) Staft) lines contained 40\% less lignin than normal lines. The present study stems from the early work by Arlel et al. (1977) who developed two normal sorghum genotypes, code named E6518 (forage type) and E1291 (dual purpose type), for the dry tropical highlands of 
Kenya. The average biomass yields of these sorghums ranged from 15 to 19 t dry matter (DM)/ha and 4 to 6 $\mathrm{t}$ grain/ha. More recently, biomass yields of 22 and $17 \mathrm{t} \mathrm{DM/ha} \mathrm{have} \mathrm{been} \mathrm{realised} \mathrm{from} \mathrm{E6518} \mathrm{and} \mathrm{E1291,}$ respectively (Njehia et al., 2000).

Sorghum production in Kenya occupies less than $18 \%$ of the land in the most suitable agro-ecological zones. This implies that a vast potential exists for promotion and expansion of sorghum cultivation, given the appropriate genotypes and comprehensive agronomic and utilisation packages. From plant breeding work reported by Njehia et al. (2000), some 13 BMR sorghum genotypes were developed, which had biomass yields ranging from 17 to $29 \mathrm{t} / \mathrm{ha}$ and grain yields of 4 to $8 \mathrm{t} / \mathrm{ha}$. The objectives of this study were to determine the nutritive characteristics of sorghum genotypes and to evaluate the effect of the BMR gene on the nutritive value of sorghums introduced into the dry highland region of Kenya.

\section{Materials and Methods}

Five sorghum genotypes (Table 1) developed at the Kenya Agricultural Research Institute (KARI), Lanet Centre were studied. The study site was located at an altitude of $1920 \mathrm{~m}$, has a mean annual rainfall of $800 \mathrm{~mm}$ and maximum and minimum temperatures of 20 and $10{ }^{\circ} \mathrm{C}$, respectively. The sorghums were of either normal WMR or BMR genotypes. The WMR genotypes were products of selections and adaptability trials which had been carried out for more than 20 years and their parent lines had been collected from the highlands of Burundi, Rwanda and Uganda. In development of the BMR genotypes, accessions of local cultivars with good agronomic characteristics were initially crossed with BMR lines introduced from Mississippi, USA. The resulting crosses underwent pedigree system of plant breeding as described by Poehlman \& Borthakur (1977) from which the current BMR genotypes were selected.

In this study two WMR genotypes, coded E1291 and E6518, and three BMR genotypes, coded Lan-5, Lan-6 and Lan-12, and silage made from E1291 were used. The silage was made by chopping the whole plants with a tractor drawn pulverizer (Taarup ${ }^{\mathrm{TM}}$ - Kidd Farm Machinery Ltd., Devizes, UK) and ensiling the chopped material in a trench silo without any additives. The cultivar (E1291) used for silage making was harvested when the grain was at the hard dough growth stage.

Samples of the chopped whole plant of the different sorghum genotypes and the silage were oven dried for $24 \mathrm{~h}$ at $55{ }^{\circ} \mathrm{C}$ and milled through a $1 \mathrm{~mm}$ sieve using a Cyclotec mill (Perstorp Analytical Ltd, Bristol, UK). The milled samples were sealed in plastic bags and stored pending laboratory study.

An in vitro manual gas production technique described by Rymer (1999) was used. Samples (1.0 \pm $0.0010 \mathrm{~g} \mathrm{DM}$ ) were weighed in triplicate and incubated together with blank samples for 24 or $72 \mathrm{~h}$ in 150 $\mathrm{mL}$ Wheaton bottles. The rumen fluid used was collected from cannulated sheep kept on a maintenance diet with a 60:40 forage to concentrate composition. The forage was sun-cured grass hay and the concentrate was a proprietary sheep pellet with a high proportion of barley.

The rumen fluid was collected into a pre-warmed $\left(39^{\circ} \mathrm{C}\right)$ vacuum flask and filtered through prewarmed glass wool and four layers of muslin cloth under continuous flushing with $\mathrm{CO}_{2}$. The buffer solution was prepared according to Goering \& Van Soest (1970). Two hours before inoculation $10 \mathrm{~mL}$ of boiled and cooled distilled water were added to the samples for soaking and then placed in an incubator at $39{ }^{\circ} \mathrm{C}$. The incubation medium was $100 \mathrm{~mL}$ with a ratio of rumen fluid to buffer of 1:5 (v/v). Settlement time of $15 \mathrm{~min}$ was allowed after which the pressure in the bottles was equilibrated by passing a needle through the stoppers to release the gas and the time recorded to mark the beginning of incubation.

Gas sampling was done every $2 \mathrm{~h}$ for the first $24 \mathrm{~h}$ and every $6 \mathrm{~h}$ thereafter up to $72 \mathrm{~h}$, according to the method described by Theodorou et al. (1994). It involved the use of a detachable pressure transducer and digital read-out voltmeter calibrated to measure head space gas pressure of fermenting cultures. After measuring the pressure and volume of the gas, sub-samples were drawn into vacutainers for analysis. At the termination of incubation $10 \mathrm{~mL}$ sub-samples of digesta fluid were drawn and prepared for short chain fatty acids (SCFA) analysis, according to the methods of MAFF (1981).

Apparent degradability (ApDeg) was calculated by subtracting the weight of dried residue after termination of incubation from that of the incubated dry material. Thereafter the neutral detergent fibre (NDF) weight of the residue was determined by the method described by Van Soest et al. (1991). True degradability (TruDeg) was similarly calculated by subtracting the NDF weight from that of the incubated material, as described by Blümmel \& Becker (1997). The difference between TruDeg and ApDeg represented microbial yields, as explained by Blümmel et al. (1997). 
Data were subjected to analysis of variance (ANOVA) to determine treatment effects whereby genotype, duration of incubation and interactions between the two were used as sources of variation. Means were compared by least significant difference (LSD) as described by Zar (1999). The Minitab (1994) computer program was used in the analyses.

\section{Results}

Neutral detergent fibre concentrations in the fresh material ranged from 514 to $726 \mathrm{~g} / \mathrm{kg} \mathrm{DM}$ (Table 1). The dual purpose genotype, E1291, had the lowest NDF and the forage genotype, E6518, the highest. The BMR genotypes had intermediate NDF concentrations. The $\mathrm{pH}$ of the digesta samples differed $(\mathrm{P}<0.001)$ after the $24 \mathrm{~h}$ incubation period among the sorghum genotypes. The lowest $\mathrm{pH}$ of 6.35 was observed in Lan6 and the highest of 6.53 in E6518. Apparent dry matter degraded (DMDeg) ranged from 343 to $479 \mathrm{~g} / \mathrm{kg}$ for the $24 \mathrm{~h}$ and 499 to $595 \mathrm{~g} / \mathrm{kg}$ for the $72 \mathrm{~h}$ incubation periods and were also influenced by genotype at $\mathrm{P}<$ 0.01 and $\mathrm{P}<0.001$, respectively, whereby E6518 had the lowest after both periods and E1291 the highest at $24 \mathrm{~h}$ while Lan-5 had the highest at $72 \mathrm{~h}$. Similarly, genotypes differed $(\mathrm{P}<0.001)$ in true degradability. True DMDeg ranged from 511 to $659 \mathrm{~g} / \mathrm{kg}$ in $24 \mathrm{~h}$ and 701 to $800 \mathrm{~g} / \mathrm{kg}$ in $72 \mathrm{~h}$. True OMDeg ranged from 520 to $678 \mathrm{~g} / \mathrm{kg}$ in $24 \mathrm{~h}$ and 706 to $805 \mathrm{~g} / \mathrm{kg}$ in $72 \mathrm{~h}$. All BMR sorghums had a higher degradability (OMD and DMD) than E6518 and the E1291 silage. The BMR genotypes, Lan-5 and Lan-12, had the highest degradability.

Table 1 Mean fibre concentration, $\mathrm{pH}$ and degradability (Deg) of five sorghum genotypes fermented in vitro in rumen liquor obtained from sheep

\begin{tabular}{|c|c|c|c|c|c|c|c|c|c|}
\hline & \multicolumn{4}{|c|}{ Brown-midrib (BMR) genotypes } & \multicolumn{3}{|c|}{ Normal genotypes } & \multirow[b]{2}{*}{ LSD } & \multirow[b]{2}{*}{$\mathrm{P}$} \\
\hline & $\begin{array}{c}\text { Time }^{\#} \\
\text { (h) }\end{array}$ & Lan-12 & Lan-5 & Lan-6 & E1291 & E6518 & $\begin{array}{l}\text { E1291 } \\
\text { silage }\end{array}$ & & \\
\hline $\begin{array}{l}\text { NDF } \\
\mathrm{g} / \mathrm{kg} \mathrm{DM}\end{array}$ & & 578 & 544 & 598 & 514 & 726 & 665 & 33 & $* * *$ \\
\hline $\mathrm{pH}$ & $\begin{array}{l}24 \\
72\end{array}$ & $\begin{array}{l}6.36 \\
6.22\end{array}$ & $\begin{array}{l}6.36 \\
6.19\end{array}$ & $\begin{array}{l}6.35 \\
6.27\end{array}$ & $\begin{array}{c}6.41 \\
-\end{array}$ & $\begin{array}{l}6.53 \\
6.39\end{array}$ & $\begin{array}{l}6.51 \\
6.39\end{array}$ & $\begin{array}{l}0.04 \\
0.03\end{array}$ & $\begin{array}{l}* * * \\
* * *\end{array}$ \\
\hline Apparent DMDeg & 24 & 420 & 432 & 411 & 479 & 343 & 408 & 30 & $* *$ \\
\hline $\mathrm{g} / \mathrm{kg}$ & 72 & 594 & 595 & 570 & - & 499 & 561 & 30 & $* * *$ \\
\hline True DMDeg & 24 & 659 & 658 & 618 & 631 & 512 & 570 & 34 & $* * *$ \\
\hline $\mathrm{g} / \mathrm{kg}$ & 72 & 753 & 800 & 777 & - & 701 & 736 & 26 & $* * *$ \\
\hline True OMDeg & 24 & 676 & 678 & 646 & 644 & 520 & 567 & 42 & $* * *$ \\
\hline $\mathrm{g} / \mathrm{kg}$ & 72 & 766 & 805 & 781 & & 706 & 738 & 29 & $* * *$ \\
\hline Microbial yield & 24 & 239 & 226 & 207 & 242 & 177 & 162 & 45 & $* *$ \\
\hline $\mathrm{g} / \mathrm{kg}$ & 72 & 159 & 205 & 203 & - & 201 & 175 & 56 & $* *$ \\
\hline
\end{tabular}

\# Duration of incubation; NDF - neutral detergent fibre; DM - dry matter; OM - organic matter; LSD - least significant difference; $* * \mathrm{P}<0.01 ; * * * \mathrm{P}<0.001$

After $24 \mathrm{~h}$ and $72 \mathrm{~h}$ of incubation, total gas production ranged from 133 to 193 and 236 to $276 \mathrm{~mL}$, respectively (Table 2). All the feeds had similar total gas productions except the normal genotype, E6518, and the E1291 silage which had the lowest $(\mathrm{P}<0.001)$ volumes in $24 \mathrm{~h}$. Methane production was also similar among the feeds over both time periods, apart from genotype, E6518, which had the lowest (P < 0.05). The amount of methane produced ranged from 21 to $28 \mathrm{~mL}$ in $24 \mathrm{~h}$ and 35 to $45 \mathrm{~mL}$ in $72 \mathrm{~h}$. Methane production/g OMDeg was similar for the feeds within both time periods, except for genotype, Lan-5, which was lower $(\mathrm{P}<0.05)$ after $72 \mathrm{~h}$ compared to the Lan-6 and Lan-12 genotypes and the E1291 silage. The amount of methane per g OMDeg ranged from 40.6 to $45.2 \mathrm{~mL} / \mathrm{g}$ in $24 \mathrm{~h}$ and 53.1 to $62.6 \mathrm{~mL} / \mathrm{g}$ in $72 \mathrm{~h}$. Lan12 had the highest methane produced per g OMDeg. 
Total SCFA production was the same for all genotypes and ranged from 7.8 to $10.4 \mathrm{mmol}$ in $24 \mathrm{~h}$ and 9.5 to $10.3 \mathrm{mmol}$ in $72 \mathrm{~h}$. Acetate to propionate ratios were also similar in both time periods and ranged from 2.16 to 2.49 in $24 \mathrm{~h}$ and 2.35 to 2.87 in $72 \mathrm{~h}$.

Table 2 Mean effects of five sorghum genotypes on rumen fermentation end-products (in vitro)

\begin{tabular}{lccccccccc}
\hline & \multicolumn{4}{c}{$\begin{array}{c}\text { Brown-midrib (BMR) } \\
\text { genotypes }\end{array}$} & \multicolumn{7}{c}{ Normal genotypes } \\
& \multicolumn{1}{c}{ Time $^{\#}(\mathrm{~h})$} & Lan-12 & Lan-5 & Lan-6 & E129 & E6518 & $\begin{array}{c}\text { E1291 } \\
\text { silage }\end{array}$ & LSD & P \\
Total gas & & & & & 1 & & & \\
$\mathrm{~mL}$ & 24 & 193 & 186 & 187 & 175 & 133 & 152 & 28 & $* * *$ \\
Total methane & 72 & 276 & 273 & 254 & - & 236 & 237 & 47 & $\mathrm{~ns}$ \\
$\mathrm{~mL}$ & 24 & 28 & 25 & 27 & 25 & 21 & 23 & 5 & $* *$ \\
Total SCFA & 72 & 45 & 35 & 41 & - & 37 & 39 & 12 & $\mathrm{~ns}$ \\
mmol & 24 & 10.4 & 7.9 & 9.4 & 8.1 & 8.3 & 7.8 & 3.1 & $\mathrm{~ns}$ \\
Total gas per OMDeg & 72 & 10.2 & 10.3 & 9.5 & - & 10.1 & 10.0 & 3.5 & $\mathrm{~ns}$ \\
mL/g & 24 & 309 & 302 & 307 & 293 & 299 & 296 & 59 & $\mathrm{~ns}$ \\
Methane per OMDeg & 72 & 385 & 363 & 368 & - & 368 & 357 & 58 & $\mathrm{~ns}$ \\
mL/g & 24 & 44.2 & 40.6 & 42.3 & 41.8 & 46.4 & 45.2 & 11.9 & $\mathrm{~ns}$ \\
Acetate:propionate & 72 & 62.6 & 53.1 & 59.1 & - & 57.4 & 61.4 & 5.9 & $*$ \\
mmol/mmol & 24 & 2.38 & 2.20 & 2.37 & 2.16 & 2.49 & 2.31 & 0.90 & $\mathrm{~ns}$ \\
& 72 & 2.37 & 2.35 & 2.38 & - & 2.87 & 2.86 & 0.95 & $\mathrm{~ns}$ \\
\hline
\end{tabular}

\# Duration of incubation; SCFA - short chain fatty acids; OMDeg - organic matter degraded;

LSD - least significant difference; $* \mathrm{P}<0.05$; ** $\mathrm{P}<0.01$; *** $\mathrm{P}<0.001$; ns - not significant

\section{Discussion}

The NDF concentrations of the sorghums used in this study were similar to the range of 511 to 624 $\mathrm{g} / \mathrm{kg}$ observed by Esmail et al. (1991) in sorghum-soya bean or sorghum silages. Similarly, Tjandraatmadja et al. (1993) observed NDF concentrations ranging from 562 to 603 and 636 to $684 \mathrm{~g} / \mathrm{kg}$ for fresh whole sorghum forages and their silages, respectively. The results of this study also agree with the findings of Tjandraatmadja et al. (1993) in terms of increased NDF in silages compared to the original plant. This was expected because non-structural carbohydrates are fermented during the silage formation process which effectively increases the NDF percentage in silage.

Rumen fermentation is sensitive to $\mathrm{pH}$, hence the importance of monitoring $\mathrm{pH}$ changes, particularly at the end of incubation in the in vitro systems. The buffer solutions used in in vitro systems are meant to maintain a stable $\mathrm{pH}$ within the normal rumen function, which has been reported to be in a range of 7.0 to 6.1 (Mould et al., 1983). Thus, it can be deduced from the current results that the values of degradability and fermentation end-products obtained represented what is expected, particularly with regard to cellulolysis which could have been inhibited at a pH below 6.0 (Mould et al., 1983). Notwithstanding, the significant differences in $\mathrm{pH}$ among the diets was most likely due to the SCFA produced from fermentation. Although the latter was not significant, there were large variations in the values obtained as opposed to those of $\mathrm{pH}$, implying that any small difference in $\mathrm{pH}$ was detectable statistically as opposed to the SCFA concentration.

The range of true DMDeg observed in the present study corresponded with the $655 \mathrm{~g} / \mathrm{kg}$ observed by Esmail et al. (1991) for sorghum fed to cattle. In an in vitro study using sorghums harvested at the hard dough stage, Meeske et al. (1993) observed a OMDeg of $676 \mathrm{~g} / \mathrm{kg}$ which is similar to that in the present study. In an in vivo study where sorghum silage was fed to goats, Tjandraatmadja et al. (1993) observed DMDeg ranging from 639 to 675 and OMD from 653 to $690 \mathrm{~g} / \mathrm{kg}$, which compare well with the current results after $24 \mathrm{~h}$ incubation. The higher degradability of BMR sorghums as compared to normal sorghums agrees with the findings of other authors (Akin et al., 1993; Streeter et al., 1993; Pedersen, 1996). The high digestibility of BMR cereals due to reduced lignin concentrations is a well known fact. Therefore, their introduction and cultivation in dry tropical highlands such as that of Kenya can enhance livestock production, besides boosting human food security. The target climate of the current study lacked adapted, 
nutritious and high yielding staple dual-purpose crops, despite attracting heavy human resettlement. The sorghums used were products of breeding work (Njehia et al., 2000) aimed at providing such crops. The E1291 genotype is a high grain yielding variety which has been promoted among farmers in the region for dual-purpose use, including silage making, as a dry season livestock feeding strategy (Ouda et al., 2003).

Blümmel et al. (1997) studied ruminant feeds using the gas production technique and defined the feed partitioning factor (PF) as the ratio of truly degraded substrate:gas produced. Generally a highly digestible feed will produce more gas than a feed with a low digestibility, but when considering feeds with comparable digestibility, the one with high PF, i.e. less gas, can be regarded to have a higher nutritive value since more of its degraded fraction is likely to be incorporated into the microbial biomass (Rymer, 1999) or be absorbed directly by the host animal. Therefore, the higher true degradability of BMR sorghums in spite of a similar gas production as the normal genotype, E1291, further indicates the higher nutritive value of the former. The other normal genotype, E6518, had the lowest degradability which may explain its lower total gas and methane productions. However, it is popular with farmers due to its high biomass yield (Njehia et al., 2000). Furthermore, the fact that the SCFA production and ratios of total gas, methane and SCFA to OMDeg were similar would suggest that the superiority shown by the BMR sorghums in terms of degradability may have an overall improved nutritive value to the ruminant.

\section{Conclusion}

There is potential to improve agricultural production in dry tropical highland climate through cultivation of adapted, high yielding and nutritious crops that can be fed to more productive livestock. Selection of sorghum genotypes which can withstand cold and moisture stress and at the same time have a high nutritive value is one way of increasing ruminant production in these regions. It has been shown in the present study that BMR genotypes had a better degradability and hence nutritive value than the normal genotypes. The current study revealed for the first time the potential of these sorghums in ruminant nutrition and this will complement the agronomic aspects reported by Njehia et al. (2000). An important implication of the finding is the potential to improve production through identifying high yielding normal sorghum genotypes with a lower nutritive value into which the brown midrib gene can be inserted to improve their nutritive value. However, the BMR sorghums used in the present study should be subjected to on-farm trials to identify ecological regions where they exhibit the desired advantage.

\section{Acknowledgement}

The authors acknowledge with thanks the support and valuable contributions of the Centre Director, K.R.G. Irungu and the laboratory technologist, W.K. Chamdany, both from KARI Lanet as well as the staff (D.I. Givens, C. Rymer, P. Kirton, L. Morgort-Valls and G. Gizzi) of ADAS Nutritional Sciences Research Unit (NSRU), UK.

\section{References}

Akin, D.E., Rigsby, L.L., Hanna, W.W. \& Lyon, C.E., 1993. In vitro digestion and textural strength of rind and pith of normal and brown midrib stems. Anim. Feed Sci. Technol. 34, 303-314.

Anindo, D.O. \& Topps J.H., 1993. The effects on production of milking crossbred suckler cows grazing a semi-arid area of Kenya. I. The productivity of the cows. E. Afr. Agric. For. J. 59 (2), 97-111.

Arkel, H.V., Creek, M.J. \& Squire, H.A., 1977. Cold tolerant sorghums: A spectacular forage crop for specific tropical applications. Wrld Rev. Anim. Prod. Vol. xiii, No. 3, 75-80.

Blümmel, M. \& Becker, K., 1997. The degradability characteristics of fifty-four roughages and roughage neutral fibre as described by in vitro gas production and their relationship to voluntary feed intake. $\mathrm{Br}$. J. Nutr. 77, 757-768.

Blümmel, M., Steinggab, H. \& Becker, K., 1997. The relationship between in vitro gas production, in vitro microbial biomass yield and $15 \mathrm{~N}$ incorporation and its implications for prediction of voluntary feed intake of roughages. Br. J. Nutr. 77, 911-921.

Esmail, S.H.M., Bolsen, K.K. \& Pfaff, L., 1991. Maturity effects on chemical composition, silage fermentation and digestibility of whole plant grain sorghum and soya-bean silages fed to beef cattle. Anim. Feed Sci. Technol. 33, 79-85. 
Goering, H.K. \& Van Soest, P.J., 1970. Forage fiber analyses (Apparatus, reagents, procedures and some applications). Agricultural Handbook No. 379, A.R.S., U.S. Dept. of Agric.

Gourley, L.M, Watson, C.E., Goggi, A.S. \& Axtel, J.D., 1997. Brown-midrib silage sorghum and Sudan grass inbreds released as germplasm. SICNA and ICRISAT. Sorghum Improvement Conference of North America. International Crops Research for the Semi-Arid Tropics, International Sorghum and Millets Newsletter 33, 58 pp.

MAFF, 1981. The Analysis of Agricultural Materials Reference Book 427, HMSO, London. 226 pp.

McCollought, R.L., Drake, C.L. \& Roth, G.M., 1972. Feedlot performance of eight hybrid sorghum grains and three hybrid corns. Kansas Agric. Exp. Sta. Bull. No. 557. pp. 21-27. (Cited by Streeter et al., 1993).

Meeske, R., Ashbell, G., Weinberg, Z.G. \& Kipnis, T., 1993. Ensiling forage sorghum at two stages of maturity with the addition of lactic acid bacterial inoculants. Anim. Feed Sci. Technol. 43, 165-175.

Minitab, 1994. Minitab for Windows-Release 10.2. Minitab Inc., Enterprise Drive, State College, PA, USA.

Mould, F.L., Ørskov, E.R. \& Mann, S.O., 1983. Associative effects of mixed feed. I. Effects of type and level of supplementation and the influence of the rumen fluid $\mathrm{pH}$ on cellulolysis in vivo and dry matter digestion of various roughages. Anim. Feed Sci. Technol.10,15-30.

Njehia, G.K., Gourley, L.M. \& Ouda, J.O., 2000. Development and evaluation of Brown-midrib sorghum genotypes for agronomic performance in dry highland areas. Proc. of $7^{\text {th }}$ KARI Biennial Scientific Conference. 13-17 Nov. 2000,. Nairobi, Kenya. pp. 253-257.

Ouda, J.O., Moss, A.R., Givens, D.I., Omed, H. \& Njehia, G.K., 2003. Yield and nutritive potential of sorghums from tropical drylands. Proc. $9^{\text {th }}$ World Congr. Animal Production. 26-31 October, Porto Alegre, Rio Grande do Sul, Brazil. p.156.

Pedersen, J.F., 1996. Annual forages: New approaches for C-4 forages. In: Progress in new crops. Ed. Janick, J., ASHS Press, Alexandria, VA. pp. 246-251.

Poehlman, J.M. \& Borthakur, D., 1977. Breeding Asian field crops with special reference to crops of India. Oxford and IBH Publishers. New Delhi, India.

Rymer, C., 1999. In vitro gas production technique: A review. Livestock Science and Biotechnology Unit, MAFF, 649 St Christopher House, Southwark Street, London, UK.

Streeter, M.N., Hill, G.M., Wagner, D.G., Hibberd, C.A. \& Owens, F.N., 1993. Chemical and physical properties and in vitro dry matter and starch digestion of eight sorghum hybrids and maize. Anim. Feed Sci. Technol. 44, 45-58.

Theodorou, M.K., Williams, B.A. \& Dhanoa, M.S., 1994. A simple gas production method using a pressure transducer to determine the fermentation kinetics of ruminant feeds. Anim. Feed Sci. Technol. 48, 185-197.

Tjandraatmadja, M., MacRae, I.C. \& Norton, B.W., 1993. Intake and digestibility of sorghum silage by goats. Anim. Feed Sci. Technol. 41,171-179.

Van Soest, P.J., Robertson, J.B. \& Lewis B.A., 1991. Methods for dietary fiber, neutral detergent fiber and non-starch polysaccharides in relation to animal nutrition. J. Dairy Sci. 74, 3583-3597.

Zar, J.H., 1999. Biostatistical Analysis (4th ed.). Prentice Hall International Inc., Upper Saddle River, New Jersey 07458 , USA. 